Journal of Telenursing (JOTING)

Volume 1, Nomor 1, Juni 2019

e-ISSN : 2684-8988

p-ISSN : 2684-8996

DOI: https://doi.org/10.31539/joting.v1i1.514

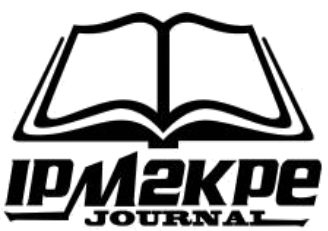

\title{
TERAPI STORY TELLING DAN MENONTON ANIMASI KARTUN TERHADAP ANSIETAS
}

\author{
Padila $^{1}$, Agusramon ${ }^{2}$, Yera $^{3}$ \\ Universitas Muhammadiyah Bengkulu ${ }^{1,2,3}$ \\ padila@umb.ac.id ${ }^{1}$
}

\begin{abstract}
ABSTRAK
Penelitian ini bertujuan untuk mengetahui perbandingan efektivitas terapi story telling dan menonton animasi kartun terhadap tingkat kecemasan akibat hospitalisasi pada anak usia pra sekolah di RS. Raflesia Kota Bengkulu. Penelitian ini menggunakan desain quasi experiment two group before after atau pre-test and post test group. Hasil penelitian menunjukan bahwa perlakuan dengan menggunakan story telling (bercerita) lebih signifikan menurunkan ansietas pada anak usia pra sekolah di RS Raflesia Kota Bengkulu dibandingkan dengan menonton animasi kartun, dilihat dari nilai hasil Uji $t 2$ sampel Independent didapatkan nilai rata-rata hasil postest ke 5 antara terapi story telling dan menonton animasi kartun yaitu 2,00 dan 8,00. Simpulan, story telling enam kali lebih cepat menurunkan kecemasan (ansietas) pada anak pra sekolah dimasa hospitalisasinya dibandingkan terapi menonton animasi kartun.
\end{abstract}

Kata Kunci : Animasi Kartun, Ansietas, Pra Sekolah, Story Telling

\section{ABSTRACT}

This study aims to determine the comparison of the effectiveness of story telling therapy and watching animated cartoons on the level of anxiety due to hospitalization in preschool aged children at the hospital. Raflesia Bengkulu City. This study used a quasi experimental design of two groups before after or pre-test and post test group. The results showed that the treatment using story telling (storytelling) was more significant in reducing anxiety in pre-school age children at Raflesia Hospital, Bengkulu City compared to watching cartoon animation, seen from the value of the t-test results of the Independent sample, the mean value of posttest results was 5. between story telling therapy and watching cartoon animation, namely 2.00 and 8.00. In conclusion, story telling is six times faster to reduce anxiety (anxiety) in pre-school children during hospitalization compared to watching cartoon animation therapy.

Keywords: Cartoon Animation, Anxiety, Pre School, Story Telling 


\section{PENDAHULUAN}

Prevalensi hospitalisasi pada anak usia pra sekolah menurut data World Health Organisation (WHO) pada tahun 2015 adalah sebanyak 45\% dari keseluruhan jumlah pasien anak usia pra sekolah yang di hospitalisasi, Sedangkan hasil survei UNICEF tahun 2013, pravalensi anak yang mengalami perawatan hospitalisasi sebanyak 84\%. Hasil survei Riset Kesehatan Dasar (RISKESDAS) tahun 2013, didapatkan data ratarata anak yang menjalani rawat inap di rumah sakit di seluruh Indonesia adalah 2,8\% dari total jumlah anak 82.666 orang. Angka kesakitan anak pra sekolah di Indonesia 2,1 juta atau sekitar 8\%. Pada anak usia pra sekolah merasakan sakit dan harus dihospitalisasi merupakan hukuman baginya dan $1 / 3$ anak usia pra sekolah mengalami hospitalisasi.

Hospitalisasi anak usia pra sekolah merupakan suatu proses yang karena suatu alasan yang berencana atau darurat, mengharuskan anak tersebut untuk tinggal di rumah sakit, menjalani terapi dan perawatan sampai pulih atau pemulangannya kembali ke rumah. Adapun penyebab dari kecemasan dipengaruhi oleh banyak faktor, baik dari petugas (perawat, dokter, dan tenaga medis lainnya), lingkungan baru, maupun keluarga yang mendampinginya (Sarfika, 2015).

Menurut Stuart \& Sundeen (2008) dampak dari hospitalisasi pada anak usia pra sekolah ada dua yaitu distress psikis seperti : (cemas, takut, marah, kecewa, sedih, malu, rasa bersalah), dan distres fisik seperti : imobilisasi, kurang tidur karena nyeri, bising, silau karena pencahayaan yang terlalu terang, sehingga anak akan mengalami rasa traumatik yang berlebihan dan tidak mau lagi dirawat di Rumah sakit bila tenaga kesehata tidak mendengarkan dan mengidentifikasi persepsi perasaan anak tersebut ketika dimasa perawatannya. Kecemasan pada anak usia prasekolah ditunjukkan dengan reaksi anak yang ketakutan akibat kurangnya pengetahuan dari anak akan penyakit, cemas karena pemisahan, takut akan rasa sakit, kurang kontrol, marah, dan menjadi regresi (James et al., 2012).

Dampak jangka panjang pada anak usia pra sekolah yang mengalami kecemasan akibat hospitalisasi adalah terhambatnya tumbuh kembang anak (Apriany, 2013). Karena pada masa ini, anak sedang dalam masa golden age atau usia keemasan, Perkembangan ini akan terhambat jika anak mengalami kecemasan akibat hospitalisasi (Haryadi, 2015). Keterlambatan perkembangan tersebut diantaranya dapat menyebabkan anak usia pra sekolah mempunyai kemampuan membaca yang buruk, kenakalan pada anak, sangat trauma setelah mengalami hospitalisasi, menurunnya kemampuan intelektual, sosial, dan fungsi imunitas pada anak (Hidayat, 2012). Hal ini selaras dari hasil penelitian yang dilakukan oleh Rennick tahun 2002 dalam Twycross et al., (2009) pada 120 pasien anak di PICU dan bangsal bedah anak. Dimana 17,5\% pasien menunjukkan kecemasan dan ketakutan pada tindakan medis 6 bulan setelah keluar dari rumah sakit dan $14 \%$ menunjukkan ketakutan pada tindakan medis yang berkelanjutan pada 6 bulan kemudian.

Sudah menjadi tugas perawat untuk memilih metode yang tepat dan menciptakan lingkungan yang nyaman ketika melakukan tindakan pada pasien anak dalam perawatan hospitalisasi (James et al., 2012). Mengatasi hal tersebut dibutuhkan suatu terapi yang merupakan bagian dari atraumatic care. Atraumatik care adalah asuhan keperawatan yang tidak menimbulkan rasa trauma baik fisik maupun psikis pada anak dan keluarga akibat setting, personel dan penggunaan intervensi tertentu seperti prosedur perawatan atau setting menyangkut tempat pemberian perawatan, misal di rumah, rumah sakit, ataupun tempat kesehatan yang lain (Fradianto, 2014). Personel menyangkut hal orang 
yang terlibat langsung dalam pemberian terapi. Dirumah sakit anak harus menghadapi lingkungan yang asing dan menerima asuhan keperawatan yang belum dikenal seperti mengalami tindakan injeksi, minum obat, Sehinga Intervensi yang harus diberikan pada anak usia sekolah tersebut harus melingkupi cakupan psikologi juga seperti contoh intervensi kejiwaan, yang mengijinkan orangtua dan anak dalam satu ruangan atau lebih dikenal dengan pendekatan family center care. Salah satu intervensi yang dapat digunakan untuk mengatasi ansietas atau kecemasan pada anak usia pra sekolah yaitu terapi story telling dan menonton animasi kartun (Supartini, 2010).

Terapi story telling merupakan salah satu teknik bermain terapeutik yang bercerita atau mendongeng dalam menyampaikan isi perasaan, buah pikiran atau sebuah cerita kepada anak-anak melalui lisan (Pratiwi, 2012). Manfaat dari kegiatan mendongeng ini antara lain adalah mengembangkan fantasi, empati dan berbagai jenis perasaan lain, menumbuhkan minat baca, membangun kedekatan dan keharmonisan, media pembelajaran. Adapun manfaat lain bagi anak dengan mendongeng antara lain adalah mengembangkan daya pikir dan imajinasi anak, mengembangkan kemampuan berbicara anak, mengembangkan daya sosialisasi anak, sarana komunikasi anak dengan orangtuanya (Nursalam, 2013). Selaras hasil penelitian Lumbansiantar (2012) menunjukkan hasil sebelum diberikannya story telling, rata-rata tingkat kecemasan pasien berada pada kategori cemas sedang, setelah diberikannya story telling rata-rata kecemasan pasien berada pada kecemasan ringan. Hal ini menunjukkan bahwa terdapat pengaruh signifikan antara pemberian story telling terhadap tingkat kecemasan akibat hospitalisasi pada anak usia prasekolah. Adapun story telling yang dilakukan dengan mendongengkan kisah Si Kancil dan Siput.

Terapi menonton animasi kartun juga merupakan salah satu terapi yang digunakan untuk mendistraksikan anak dari rasa ansietasnya (Lee, 2012). Terapi ini merupakan mengalihkan perhatian anak ke hal yang lain sehingga dapat menurunkan kewaspadaan terhadap nyeri, bahkan meningkatkan toleransi terhadap nyeri (Maharezi, 2014). Sehingga dapat mengurangi tingkat kecemasan anak. Perawat dapat mengkaji aktivitasaktivitas yang dinikmati klien sehingga dapat dimanfaatkan sebagai distraksi. Aktivitas tersebut dapat meliputi kegiatan menyanyi, berdoa, menceritakan foto atau gambar dengan suara keras, mendengarkan musik, dan bermain (Santoso et al., 2009). Sebagian besar distraksi dapat digunakan di rumah sakit, di rumah, atau pada fasilitas perawatan jangka panjang (Tamsuri, 2007).

Film kartun animasi mengandung unsur gambar, warna, dan cerita sehingga anak-anak menyukai menonton film kartun animasi (Windura, 2008). Ketika anak lebih fokus pada kegiatan menonton film kartun, hal tersebut membuat anak fokus pada kegiatan menonton sehingga ketika hendak dilakukan tindakan keperawatan, kecemasan anak teralihkan. Hal ini senada dengan penelitian Adnanda (2016) menunjukkan adanya perbedaan hasil nilai rerata yang signifikan pada skala kecemasan antara kelompok eksperimen yang diberi perlakuan distraksi menonton animasi kartun dengan kelompok yang tidak diberikan perlakuan. Terapi menonton animasi kartun yang digunakan dalam penelitian ini adalah kisah Si Kancil dan Siput. Dengan terapi story telling dan menonton animasi kartun, anak mampu bersikap kooperatif dan terminimalisir ansietasnya (Pravitasari \& Edi, 2014). 


\section{METODE PENELITIAN}

Jenis penelitian ini adalah quasi experiment, dengan desain yang digunakan adalah two group before after atau pre-test and post test group design. Dimana kedua kelompok mendapatkan suatu perlakuan tertentu pada masing-masing kelompok, pengambilan sampel dilakukan dengan menggunakan kelompok eksperiment antara 10-20 sampel. Sampel dalam penelitian ini diambil berdasarkan kriteria inklusi yaitu anak usia pra sekolah berumur 3-5 tahun, tidak dalam keadaan kritis, minimal hari perawatan 2 hari, orang tua dan anak bersedia menjadi responden dan anak mengalami kecemasan sedang, berdasarkan kriteria tersebut didapatkan sampel berjumlah 20 orang, dibagi dalam 2 kelompok, 10 orang untuk kelompok dengan perlakuan story telling dan 10 orang untuk kelompok dengan perlakuan menonton animasi kartun. Masing-masing perlakuan diberikan selama 3 hari masa hospitalisasi pada anak.

Pelaksanaan perlakuan terapi story telling dan menonton animasi kartun adalah dengan memberitahukan kepada orangtua tentang manfaat, tujuan dan prosedur kegiatan. Setelah orangtua setuju maka responden diminta mengisi instrument tingkat kecemasan pada instrument penelitian yang dibantu oleh orangtuanya, Setelah 30 menit kemudian menyiapkan media seperti buku cerita tentang kisah "Si Kancil dan Siput" untuk terapi story telling, dan menggunakan tablet ukuran 10 inci untuk terapi menonton animasi kartun Si Kancil dan Siput, setelah itu melakukan pendekatan psikologis dengan memperkenalkan diri kepada anak, selanjutnya memulai bencerita selama 20 menit pada kelompok terapi story telling dan menonton pada kelompok animasi kartun.

Untuk mengukur tingkat kecemasan pada anak usia pra sekolah menggunakan pengukuran skala Preschool Anxiety Scale (PAS). Setalah data terkumpul, ditabulasi dan dianalisis dengan menggunakan metode Uji $t 2$ sampel Independent yaitu merupakan prosedur uji $\mathrm{t}$ untuk sampel bebas dengan membandingkan rata-rata dua kelompok kasus.

\section{HASIL PENELITIAN Analisis Unvariat}

Tabel. 1

Distribusi Responden Berdasarkan Karakteristik Responden

\begin{tabular}{llcc}
\hline No & Variabel & Frekuensi & Persentase \\
\hline \multirow{4}{*}{1} & Umur & & \\
& 3 Tahun & 9 & 45 \\
& 4 Tahun & 6 & 30 \\
& 5 Tahun & 5 & 25 \\
\hline & Total & 20 & 100 \\
\hline \multirow{2}{*}{2} & Jenis Kelamin & & \\
& Laki-laki & 11 & 55 \\
& Perempuan & 9 & 45 \\
\hline & Total & 20 & 100 \\
\hline \multirow{2}{*}{3} & Urutan Kelahiran & & \\
Anak pertama & 10 & 50 \\
& Anak tengah & 7 & 35 \\
& Anak terakhir & 3 & 15 \\
\hline & Total & 20 & 100 \\
\hline
\end{tabular}


Berdasarkan tabel 1 menunjukkan bahwa pada penelitian ini, anak pra sekolah yang mengalami hospitalisasi hampir sebagian (45\%) berumur 3 tahun. Sedangkan jenis kelamin anak pra sekolah yang mengalami hospitalisasi di Rumah Sakit Rafflesia sebagian besar (55\%) adalah anak laki-laki dengan urutan kelahiran sebagian (50\%) anak pertama.

Tabel. 2

Distribusi Frekuensi Kecemasan Sebelum dan Setelah pada Kelompok Intervensi Terapi Story Telling

\begin{tabular}{lccccc}
\hline Variabel & $\begin{array}{c}\text { Mean } \\
\text { Median }\end{array}$ & SD & Min-Mak & $95 \%$ CI & $\begin{array}{c}\text { Total Selisih } \\
\text { Means pre-post } \\
\text { 5ea }\end{array}$ \\
\hline Pretest & 26,71 & 3,0 & $16-35$ & $23,00-27,03$ & \\
Postest 1 & 25,06 & 3,6 & $15-37$ & $21,83-28,29$ & \\
Postest 2 & 27,41 & 4,9 & $21-33$ & $25,57-29,26$ & \\
Postest 3 & 12,82 & 4,1 & $6-19$ & $10,73-14,92$ & \\
Postest 4 & 11,82 & 4,1 & $4-17$ & $9,72-13,93$ & $21,59-24,03$. \\
Postest 5 & 2,24 & 1,6 & $0-7$ & $1,41-3,00$ & \\
\hline
\end{tabular}

Berdasarkan tabel 2 dengan memperhatikan hasil distribusi nilai pada pre test dan post test intervensi terapi Story telling didapatkan rata-rata tingkat kecemasan pretest 26,71, median 26, (95\% CI = 23,78-27,63) dengan SD 3,0, nilai skor pretest terendah 16 dan tertinggi 35. Dari hasil estimasi interval disimpulkan bahwa $95 \%$ diyakini bahwa rata-rata pretest kelompok intervensi terapi story telling adalah 23,00 - 27,03.

Berdasarkan tabel 2 dengan memperhatikan hasil distribusi nilai pada postest ke 5 setelah intervensi terapi Story telling didapatkan rata-rata posttest 2,24, median 2, (95\% $\mathrm{CI}=1,41-3,00)$ dengan SD 1,6, nilai skor postest terendah 0 dan tertinggi 7 . Dari hasil estimasi interval disimpulkan bahwa 95\% diyakini bahwa rata-rata postest dengan kelompok intervensi terapi Story telling adalah 1,41-3,00.

Dari hasil estimasi interval disimpulkan bahwa 95\% diyakini bahwa rerata perubahan tingkat kecemasan anak usia pra sekolah sebelum intervensi terapi Story telling adalah 23,00 - 27,03, dan setelah dilakukan terapi Story telling pada posttest ke 5 menjadi 1,41-3,00 terlihat selisih menurunnya sebanyak 21,59-24,03.

Tabel. 3

Distribusi Frekuensi Kecemasan Sebelum dan Setelah pada Kelompok Intervensi Terapi Menonton Animasi Kartun

\begin{tabular}{lccccc}
\hline Variabel & $\begin{array}{c}\text { Mean } \\
\text { Median }\end{array}$ & SD & $\begin{array}{c}\text { Min- } \\
\text { Maks }\end{array}$ & $95 \%$ CI & $\begin{array}{c}\text { Total selisih } \\
\text { Means pre- } \\
\text { post 5 }\end{array}$ \\
\hline Pretest & 26,15 & 4,5 & $16-36$ & $23,05-27,65$ & \\
Postest 1 & 26,01 & 4,2 & $17-34$ & $24,56-28,85$ & \\
Postest 2 & 25,26 & 4,9 & $17-36$ & $23,74-28,84$ & \\
Postest 3 & 15,06 & 4,9 & $10-26$ & $12,53-17,59$ & $14,31-15,27$ \\
Postest 4 & 13,53 & 3,1 & $10-20$ & $11,91-15,15$ & \\
Postest 5 & 9,06 & 2,6 & $4-12$ & $8,74-12,38$ & \\
\hline
\end{tabular}


Berdasarkan tabel 3 dengan memperhatikan hasil pada pretest dan posttest intervensi terapi Menonton Animasi Kartun didapatkan nilai rata-rata pretest 26,15, median 26,00, $(95 \% \mathrm{CI}=24,05-28,65)$ dengan SD 4,5, nilai pretest terendah 16 dan tertinggi 36. Dari hasil estimasi interval disimpulkan bahwa 95\% diyakini bahwa rerata perubahan tingkat kecemasan pada anak pra sekolah sebelum intervensi adalah 23,05 27,65 .

Berdasarkan tabel 3 dengan memperhatikan hasil pada postest ke 5 intervensi didapatkan nilai rata-rata postest 9,06, median 9,00, (95\% $\mathrm{CI}=7,74-10,38)$ dengan SD 2,6 , nilai postest terendah 4 dan tertinggi 12. Dari hasil estimasi interval disimpulkan bahwa 95\% diyakini bahwa rata-rata postest perubahan rerata perubahan tingkat kecemasan pada anak dengan kelompok intervensi adalah 8,74-12,38.

Dari hasil estimasi interval disimpulkan bahwa 95\% diyakini bahwa rerata perubahan tingkat kecemasan pada anak sebelum intervensi terapi menonton animasi kartun adalah 23,05 - 27,65, dan setelah dilakukan terapi menonton animasi kartun pada posttest ke 5 menjadi 8,74-12,38 terlihat selisih menurunnya rerata sebanyak 14,31-15,27.

Tabel. 4

Hasil Uji Normalitas Tingkat Kecemasan Anak Usia Prasekolah Kelompok Intervensi Terapi Story Telling

\begin{tabular}{lccc}
\hline Variabel & p-value & Hasil uji normalitas & Uji statistik \\
\hline Pretest & 0,23 & Normal & \\
Postest 1 & 1,00 & Normal & \\
Postest 2 & 0,70 & Normal & Skewnees \\
Postest 3 & 0,68 & Normal & \\
Postest 4 & 0,79 & Normal & \\
Postest 5 & 0,07 & Normal & \\
\hline
\end{tabular}

Berdasarkan tabel 4 memperlihatkan bahwa tingkat kecemasan hasil uji normalitas anak pra sekolah kelompok intervensi terapi story telling sebelum dan setelah intervensi menghasilkan nilai skewness dibagi standar error $<2$, hal ini menunjukkan bahwa semua data baik sebelum dan sesudah intervensi berdistribusi normal.

Tabel. 5

Hasil Uji Normalitas Tingkat Kecemasan Anak Usia Prasekolah Kelompok Intervensi Terapi Menonton Animasi Kartun

\begin{tabular}{lccc}
\hline \multicolumn{1}{c}{ Variabel } & p-value & Hasil uji normalitas & Uji statistik \\
\hline Pretest & 0,20 & Normal & \\
Postest 1 & 1,72 & Normal & \\
Postest 2 & 0,49 & Normal & Skewness \\
Postest 3 & 0,36 & Normal & \\
Postest 4 & 0,63 & Normal & \\
Postest 5 & 0,34 & Normal & \\
\hline
\end{tabular}

Berdasarkan tabel 5 memperlihatkan bahwa hasil uji normalitas pada tingkat kecemasan anak usia prasekolah kelompok intervensi terapi menonton animasi kartun dengan menggunakan analisis statistik skewness pada kelompok intervensi sebelum dan 
setelah intervensi menghasilkan nilai skewness dibagi standar error $<2$, hal ini menunjukkan bahwa semua data baik sebelum dan sesudah intervensi berdistribusi normal.

Tabel. 6

Hasil Uji Homogenitas Varians Tingkat Kecemasan Anak Usia Prasekolah Kelompok Intervensi Terapi Story Telling dan Menonton Animasi Kartun

\begin{tabular}{llcl}
\hline Variabel & & Levene's test & $\begin{array}{c}\text { Hasil uji homogenitas } \\
\text { varians }\end{array}$ \\
\hline $\begin{array}{l}\text { Pretest- } \\
\text { Protest }\end{array}$ & $\begin{array}{l}\text { Equal variances assumed } \\
\text { Equal variances not assumed }\end{array}$ & 0,07 & Homogen \\
\hline
\end{tabular}

Berdasarkan tabel 6 memperlihatkan bahwa hasil uji homogenitas varians dengan menggunakan uji levene's test diatas menghasilkan nilai $\mathrm{p}=0,07>0,05$ artinya dapat disimpulkan bahwa variasi kedua kelompok intervensi baik kelompok terapi Story telling dan menonton animasi kartun sama atau disebut homogen.

Tabel. 7

Hasil Uji Perbedaan Tingkat Kecemasan Anak Usia Prasekolah Kelompok Intervensi Terapi Story Telling Sebelum dan Setelah Terapi

\begin{tabular}{lccc}
\hline & Variabel & Sig. (2-tailed) & Uji statistik \\
\hline Pair 1 & Pretest -- Postest 1 & .642 & Paired t test dengan uji t 2 \\
Pair 2 & Pretest - Postest 2 & .177 & sampel dependen \\
Pair 3 & Pretest - Postest 3 & .000 & \\
Pair 4 & Pretest - Postest 4 & .000 & \\
Pair 5 & Pretest - Postest 5 & .000 & \\
\hline
\end{tabular}

Berdasarkan tabel 7 memperlihatkan bahwa hasil uji $2 \mathrm{t}$ dependent terapi Story telling hasil pretest-postest 3, 4 dan 5 p-valuenya $=0,000$. Maka dapat disimpulkan hasil nilai $\mathrm{p}$ nya $<0,05$ artinya ada perbedaan yang signifikan rata-rata tingkat kecemasan pretest dan posttest ke 3,4 dan 5 pada anak usia prasekolah kelompok intervensi terapi story telling.

Tabel. 8

Hasil Uji Perbedaan Tingkat Kecemasan Anak Usia Prasekolah Kelompok Intervensi Terapi Menonton Animasi Kartun Sebelum dan Setelah Terapi

\begin{tabular}{cccc}
\hline & Variabel & Sig. (2-tailed) & Uji statistik \\
\hline Pair 1 & Pretest--Postest 1 & .783 & Paired t test dengan \\
Pair 2 & Pretest - Postest 2 & .962 & uji t 2 sampel \\
Pair 3 & Pretest - Postest 3 & .000 & dependen \\
Pair 4 & Pretest - Postest 4 & .000 & \\
Pair 5 & Pretest - Postest 5 & .000 & \\
\hline
\end{tabular}

Berdasarkan tabel 8 memperlihatkan bahwa hasil uji 2 t dependent terapi Story telling hasil pretest-postest 3, 4 dan 5 p-valuenya $=0,000$. Maka dapat disimpulkan hasil nilai $\mathrm{p}$ nya $<0,05$ artinya ada perbedaan yang signifikan rata-rata tingkat 
kecemasan pretest dan posttest ke 3,4 dan 5 pada anak usia prasekolah Kelompok intervensi terapi menonton animasi kartun.

Tabel. 9

Hasil Uji Perbedaan Tingkat Kecemasan Anak Usia Pra Sekolah

Setelah Diberikan Terapi pada Kedua Kelompok Intervensi

\begin{tabular}{lcccc}
\hline & Variabel & N & Sig. (2-tailed) & Uji statistik \\
\hline Postest 1 & Story telling & 10 & 25,06 & \\
& menonton animasi kartun & 10 & 26,71 & \\
\cline { 1 - 4 } Postest 2 & Story telling & 10 & 24,41 \\
& menonton animasi kartun & 10 & 25,29 & \\
\cline { 1 - 3 } Postest 3 & Story telling & 10 & 12,82 & \\
& menonton animasi kartun & 10 & 15,06 & \\
& Story telling & 10 & 10,80 & \\
Postest 4 & independent & \\
& menonton animasi kartun & 10 & 14,50 & \\
\cline { 1 - 3 } Postest 5 & Story telling & 10 & 2,04 & \\
& menonton animasi kartun & 10 & 8,00 & \\
\hline
\end{tabular}

Berdasarkan tabel 9 setelah diberikan terapi pada kedua kelompok dapat dilihat pada hasil postest ke 5 antara terapi story telling dan terapi menonton animasi kartun didapatkan nilai rata-rata 2,04 dan 8,02. Semakin kecil hasil nilai rerata pada kedua kelompok setelah intervensi menunjukkan semakin menurunnya kecemasan pada anak, dari hasil posttest ke 5 story telling nilai reratanya lebih kecil dari menonton animasi kartun artinya ada perbedaan yang signifikan rerata anak usia sekolah yang mengalami hospitalisasi setelah diberikan intervensi terapi story telling skor kecemasan pada anak jauh lebih menurun dari pada terapi menonton animasi kartun.

\section{PEMBAHASAN}

Berdasarkan tabel 1 menunjukkan bahwa pada penelitian ini, anak pra sekolah yang mengalami hospitalisasi di Rumah Sakit Rafflesia Bengkulu, hampir sebagian berumur 3 tahun. Berjenis kelamin sebagian besar adalah anak laki-laki dengan urutan kelahiran sebagian adalah anak pertama.

Hal tersebut diatas sejalan dengan pernyataan Utami (2014) yang menyatakan bahwa anak usia 3 tahun masih sangat rentan terkena penyakit dibandingkan usia anak diatasnya. Anak usia 3 tahun belum mengerti mana yang kotor dan yang bersih, terkadang anak sangat sering memungut makanan yang jatuh dari lantai kemudian memakannya kembali, sehingga tanpa pengawasan yang ketat dari orang tuanya menyebabkan anak mudah terkena penyakit seperti diare, batuk dan flu. Maka dapat disimpulkan semakin muda usia anak akan lebih berisiko untuk mengalami hospitalisasi disebabkan oleh pertahanan sistem imun anak yang masih berkembang sehingga sangat rentan terhadap paparan penyakit.

Jenis kelamin anak pra sekolah yang mengalami hospitalisasi pada penelitian ini terbanyak dialami oleh anak laki-laki yaitu 6 anak pada kelompok terapi story telling dan 5 anak pada kelompok menonton animasi kartun. Hal ini dikarenakan anak laki-laki lebih banyak melakukan aktifitas dan kurang teratur dalam pola tidur dan makan karena asyik bermain (Parker \& Wampler, 2010). Sehingga anak laki-laki sering mengalami sakit dibandingkan anak perempuan. Selain itu pada penelitian ini, keterbatasan aktivitas akibat hospitalisasi menyebabkan anak laki-laki lebih lama mengalami hari 
rawat dibandingkan anak perempuan. Disamping itu Anak perempuan pada umumnya lebih adaptif terhadap stressor dibandingkan dengan anak laki-laki. Adapun yang mengawali atau mencetuskan perubahan disebut stressor. Stressor menunjukkan suatu kebutuhan yang tidak terpenuhi dan kebutuhan tersebut bisa saja kebutuhan fisiologis, psikologis, sosial, dan lingkungan (Parker \& Wampler, 2010).

Berdasarkan karakteristik urutan kelahiran didapatkan data bahwa urutan kelahiran anak yang paling banyak mengalami kecemasan adalah anak pertama yang berjumlah 10 orang dari dua kelompok terapi.

Hasil penelitian ini senada dengan pernyataan Brannon et al., (2013) yang menyatakan bahwa anak pertama biasanya mendapat perhatian penuh karena belum ada saudara lain. Segala kebutuhan dipenuhi, tetapi biasanya orang tua belum mempunyai banyak pengalaman dalam mengasuh anak dan cenderung selalu melindungi anaknya sehinngga anak tumbuh menjadi anak perfeksionis dan cenderung pencemas. Anak tengah berada antara anak tertua dan anak bungsu/terakhir, anak mempunyai kesempatan untuk belajar berkomunikasi dan lebih mampu beradaptasi diantara anak terbesar dan anak terkecil. Hal tersebut membuat anak lebih mandiri. Anak terakhir atau anak bungsu biasanya mendapat perhatian penuh dari semua anggota keluarga sehingga membuat anak mempunyai kepribadian yang hangat, ramah, dan penuh perhatian pada orang lain (Haryadi, 2015).

Berdasarkan tabel 2 disimpulkan bahwa rerata perubahan tingkat kecemasan anak usia pra sekolah sebelum intervensi terapi Story telling adalah 23,00 - 27,03, dan setelah dilakukan terapi Story telling pada posttest ke 5 menjadi 1,41-3,06 terlihat selisih menurunnya sebanyak 20,37-17,57.

Terapi story telling merupakan salah satu teknik bermain terapeutik yang bercerita atau mendongeng dalam menyampaikan isi perasaan, buah pikiran atau sebuah cerita kepada anak-anak melalui lisan (Pratiwi, 2012). Manfaat dari kegiatan mendongeng ini antara lain adalah mengembangkan fantasi, empati dan berbagai jenis perasaan lain, menumbuhkan minat baca, membangun kedekatan dan keharmonisan, media pembelajaran. Adapun manfaat lain bagi anak dengan mendongeng antara lain adalah mengembangkan daya pikir dan imajinasi anak, mengembangkan kemampuan berbicara anak, mengembangkan daya sosialisasi anak, sarana komunikasi anak dengan orangtuanya (Nursalam, 2013).

Hasil penelitian ini senada dengan pendapat Hawari (2011) yang menyatakan bahwa kecemasan adalah respon emosional terhadap penilaian yang menggambarkan keadaan kecemasan, kekhawatiran, gelisah, takut di sertai berbagai keluha fisik. Seseorang akan mengalami gangguan kecemasan manakala yang bersangkutan tidak mampu mengatasi stressor psikososial yang dihadapinya.

Dari hasil penelitian, perlakuan terapi story telling mampu menurunkan tingkat kecemasan pada anak karena ketakutan anak menjadi berkurang, anak menjadi lebih akrab dengan perawat dan lebih familiar dengan lingkungan rumah sakit serta anak tidak akan merasa jenuh karena waktu mereka diisi dengan kegiatan mendongeng dan bercerita. Story telling memiliki beberapa keuntungan dibandingkan dengan terapi yang lainnya, karena pemberian story telling dapat memberikan kesenangan kepada anak, secara naluri anak usia pra sekolah memiliki kesenangan dalam mendengarkan cerita. Selain itu terapi mendongeng sangat efektif diberikan kepada anak yang memiliki keterbatasan energi untuk bermain. Terapi story telling dapat menciptakan suasana akrab antara anak dengan pendongeng sehingga dapat mengurangi tingkat kecemasan 
anak dan dapat menjadi penyaluran emosi yang terbendung pada diri anak (Supartini, 2010).

Berdasarkan tabel 3 dari hasil estimasi interval disimpulkan bahwa 95\% diyakini bahwa rata-rata postest perubahan rerata perubahan tingkat kecemasan pada anak dengan kelompok intervensi adalah 8,74 - 12,38. Dari hasil estimasi interval disimpulkan bahwa 95\% diyakini bahwa rerata perubahan tingkat kecemasan pada anak sebelum intervensi terapi menonton animasi kartun adalah 23,05 - 27,65, dan setelah dilakukan terapi menonton animasi kartun pada posttest ke 5 menjadi 8,74-12,38 terlihat selisih menurunnya rerata sebanyak 15,03 -19,20.

Distraksi melalui audiovisual adalah salah satu bentuk pengalihan perhatian yang efektif untuk anak usia pra sekolah, hal tersebut dikarenakan di dalam distrkasi audiovisual menayangan tokoh kartun lucu yang memberikan edukasi kesehatan dalam bahasa yang sederhana dan menarik, sehingga membuat anak merasa senang, terhibur dan mendapat nilai edukasi. Respons baik yang paling dominan setelah pemberian terapi audiovisual adalah anak mampu mengurangi sikap kasar terhadap perawat seperti mencubit atapun menendang dan tidak lagi menyembunyikan tangan saat dilakukan tindakan injeksi (Dianita. 2016). Hal ini senada dengan penelitian Rahmah (2015) yang menunjukkan bahwa pada dasarnya anak tidak dapat bersikap tenang dan tidak ingin jauh dari orangtua selama perawat memberikan tindakan injeksi intravena melalui saluran infus, hanya saja dengan adanya distraksi melaui audivisual dapat mengurangi respons negatif tersebut. Hal tersebut menyebabkan anak yang diberikan distraksi audiovisual menunjukkan respons penerimaan yang lebih baik dibandingkan anak yang hanya mendapat perawatan rutin ruangan (tanpa distraksi audiovisual) (Parker \& Wampler, 2010).

Audivisual yang dapat kita berikan tentunya yang sesuai dengan usia anak, seprerti kartun animasi, Anak usia prasekolah sangat mudah dialihkan, salah satunya dengan menonton animasi kartun sehingga teknik distraksi dapat membantu dalam manajemen nyeri dan cemas (Supartini, 2010). Selain itu teknik ini lebih mudah dan dapat dilakukan oleh perawat (Twycross et al., 2009). Penelitian teknik distraksi menonton kartun animasi ini sejalan dengan penelitian yang dilakukan beberapa ahli seperti James et al., (2012) dengan menggunakan desain penelitian quasi-eksperimen. Penelitian tersebut bertujuan untuk melihat pengaruh menonton film kartun animasi terhadap respon prilaku dari kecemasan dan persepsi nyeri anak usia prasekolah yang menjalani venipuncture. Hasil dari penelitian ini menunjukan bahwa adanya penurunan cemas dan nyeri yang signifikan setelah anak menonton film kartun saat dilakukan venipunctur. Dari hasil penelitian tersebut peneliti menyarankan bahwa menonton film kartun dapat digunakan untuk mengatasi respon prilaku cemas dan nyeri anak saat menjalani tindakan invasif secara efektif. Senada dengan hasil penelitian Baljit (2014) yang menyatakan bahwa menonton animasi kartun saat dilakukannya tindakan invasif berpengaruh signifikan menurunkan kecemasan dengan nilai $\mathrm{p}_{\text {_value }}<0,005$.

\section{Analisa Inferens}

Berdasarkan tabel 7 ada perbedaan yang signifikan rata-rata tingkat kecemasan pretest dan posttest ke 3,4 dan 5 pada anak usia prasekolah kelompok intervensi terapi story telling.

Terapi story telling merupakan salah satu teknik bermain terapeutik yang bercerita atau mendongeng dalam menyampaikan isi perasaan, buah pikiran atau sebuah cerita kepada anak-anak melalui lisan (Pratiwi, 2012). Manfaat dari kegiatan mendongeng ini 
antara lain adalah mengembangkan fantasi, empati dan berbagai jenis perasaan lain, menumbuhkan minat baca, membangun kedekatan dan keharmonisan, media pembelajaran. Adapun manfaat lain bagi anak dengan mendongeng antara lain adalah mengembangkan daya pikir dan imajinasi anak, mengembangkan kemampuan berbicara anak, mengembangkan daya sosialisasi anak, sarana komunikasi anak dengan orangtuanya (Nursalam, 2013). Selaras hasil penelitian Lumbansiantar (2012) menunjukkan hasil sebelum diberikannya story telling, rata-rata tingkat kecemasan pasien berada pada kategori cemas sedang, setelah diberikannya story telling rata-rata kecemasan pasien berada pada kecemasan ringan. Hal ini menunjukkan bahwa terdapat pengaruh signifikan antara pemberian story telling terhadap tingkat kecemasan akibat hospitalisasi pada anak usia prasekolah. Adapun story telling yang dilakukan dengan mendongengkan kisah Si Kancil dan Siput.

Story telling terdiri atas dua kata yaitu story berarti cerita dan telling berarti penceritaan. Penggabungan dua kata story telling berarti penceritaan cerita atau menceritakan cerita. Hasil penelitian ini selaras dengan teori menurut Asfandiyar (2007) yang menyatakan bahwa dalam penatalaksanaan anak dengan kecemasan, story telling merupakan salah satu intervensi yang efektif dapat diberikan oleh perawat anak pada saat melakukan tindakan yang menimbulkan rasa nyeri dan cemas, hal ini dikarenakan story telling merupakan suatu proses kreatif yang dapat diberikan pada anak-anak usia pra sekolah yang dalam masa perkembangannya, karena lewat bercerita akan mengaktifkan bukan hanya aspek intelektual saja tetapi juga aspek kepekaan, kehalusan budi, emosi, seni, daya berfantasi, dan imajinasi anak yang tidak hanya mengutamakan kemampuan otak kiri tetapi juga otak kanan. Cerita mengandung nilai edukatif, yaitu: mengembangkan kemampuan berbahasa, mengembangkan kemampuan membaca, mengembangkan kepekaan terhadap cerita, meningkatkan kemampuan menulis, membantu perkembangan aspek sosial, membantu perkembangan aspek emosional, membantu perkembangan aspek kreativitas, dan membantu perkembangan aspek kognitif (Asfandiyar, 2007).

Hasil penelitian ini selaras dengan hasil penelitian Kanchan (2014) yang menyatakan bahwa Hasil uji dengan pendekatan quasi eksperiment dengan pretestposttest group control design. Hasilnya adalah dari terapi bermain melalui bercerita menunjukkan bahwa ada penurunan yang signifikan dalam skor kecemasan rawat inap pasca terapi pada anak usia sekolah dibuktikan dengan nilai $\mathrm{z}=-8.243, \mathrm{p}<0,05$.

Berdasarkan tabel 8 memperlihatkan bahwa ada perbedaan yang signifikan ratarata tingkat kecemasan pretest dan posttest ke 3,4 dan 5 pada anak usia prasekolah Kelompok intervensi terapi menonton animasi kartun.

Hasil penelitian ini selaras dengan teori menurut Wong (2009) yang menyatakan bahwa penatalaksanaan kecemasan pada anak dapat dilakukan dengan cara mengajak anak menonton bersama salah satunya adalah terapi menonton animasi kartun, ini merupakan salah satu terapi yang masuk pada kategori atraumatic care. Dimana pada film kartun animasi terdapat unsur gambar, warna, dan cerita sehingga anak-anak menyukai menonton film kartun animasi (Windura, 2008). Ketika anak lebih fokus pada kegiatan menonton film kartun, hal tersebut membuat impuls nyeri akibat adanya cidera tidak mengalir melalui tulang belakang, pesan tidak mencapai otak sehingga anak tidak merasakan nyeri dan membuat anaknya tidak menjadi cemas (Brannon et al., 2013).

Hasil penelitian ini selaras dengan penelitian Sarfika (2015) dimana berdasarkan hasil penelitiannya, didapatkan adanya perbedaan tingkat kecemasan yang bermakna antara pre test dan post test pada kelompok anak usia pra sekolah yang diberikan teknik 
distraksi audio visual selama sirkumsisi. Ini berarti bahwa pemberian teknik distraksi terbukti efektif dalam menurunkan kecemasan anak baik secara subyektif maupun secara obyektif.

Berdasarkan tabel 9 Dari hasil penelitian setelah diberikan terapi pada kedua kelompok dapat dilihat pada hasil postest ke 5 antara terapi Story telling dan terapi menonton animasi kartun didapatkan nilai rata-rata 2,04 dan 8,02. Semakin kecil hasil nilai rerata pada kedua kelompok setelah intervensi menunjukkan semakin menurunnya kecemasan pada anak, dari hasil posttest ke 5 Story telling nilai reratanya lebih kecil dari menonton animasi kartun artinya ada perbedaan yang signifikan rerata anak usia sekolah yang mengalami hospitalisasi setelah diberikan intervensi terapi Story telling skor kecemasan pada anak jauh lebih menurun dari pada terapi menonton animasi kartun.

Kecemasan adalah respon emosi tanpa objek yang spesifik yang secara subyektif dialami dan dikomunikasikan secara interpersonal (Keliat, 1999). Kecemasan adalah kebingungan, kekhawatiran pada sesuatu yang akan terjadi dengan penyebab yang tidak jelas dan dapat dihubungkan dengan perasaan tidak menentu dan tidak berdaya. Reaksi tersebut bersifat individual dan sangat bergantung pada tahap usia perkembangan anak, pengalaman sebelumnya terhadap sakit, sistem dukungan yang tersedia, dan kemampuan koping yang dimiliknya (Sugihartiningsih, 2016).

Tingkat kecemasan yang berbeda pada tiap anak disebabkan karena respons setiap manusia terhadap stressor memang berbeda-beda. Hal ini sesuai dengan model kognitif kecemasan yang disampaikan oleh Subardiah (2009) yang menyebutkan bahwa respons yang berbeda pada tiap individu antara lain dipengaruhi oleh adanya kelemahan dalam berbagai proses informasi. Penyebab lain yang mempengaruhi tingkat kecemasan yang berbeda adalah adanya sistem pendukung yaitu pendampingan orangtua atau orang terdekat anak sehingga anak berespons berbeda terhadap stressor.

Hasil penelitian ini selaras dengan teori menurut Hawari (2011) menyatakan bahwa tingkat kecemasan subyektif seseorang tidak selalu berhubungan dengan keseriusan prosedur bedah saja, ini terbukti pada beberapa responden dalam penelitian ini merasa mengalami tingkat kecemasan yang sedang (skala 6 dari 10) saat prosedur pengambilan darah dan injeksi sebelum dilakukan terapi padahal tindakan ini sudah berulang dilakukan akan tetapi tetap menimbulkan kecemasan secara obyektif dengan menggunakan pengukuran denyut nadi per menit, didapatkan rerata denyut nadi per menit yang cukup tinggi. Hal ini disebabkan adanya salah satu respons fisiologis dari kecemasan berupa peningkatan denyut nadi permenit (Keliat, 1999).

Hasil penelitian ini, dari hasil posttest ke 5 story telling nilai reratanya lebih kecil dari menonton animasi kartun artinya ada perbedaan yang signifikan rerata anak usia sekolah yang mengalami hospitalisasi setelah diberikan intervensi terapi story telling, skor kecemasan pada anak jauh lebih menurun dari pada terapi menonton animasi kartun. Hal ini dapat dipengaruhi oleh karakteristik perkembangan anak usia pra sekolah, dimana anak lebih senang jika diberikan dongeng atau diceritakan film-film kartun ketimbang anak yang menonton sendiri, karena lewat audio suara secara langsung yang diberikan oleh perawat membuat anak akan sangat terdistraksi dan mampu mengalihkan rasa cemasnya, seperti teori berikut yang menggunakan teknik distraksi untuk mengalihkan fokus perhatian dari rasa cemas, rasa takut akibat pembedahan, tindakan invasif, lingkungan asing dan Intervensi kognitif yang tepat salah satunya adalah penggunaan audio (Windura, 2008). 
Penerapan stimulasi baik bercerita ataupun dengan audio berdampak positif bagi perkembangan emosional anak dengan pendekatan Johnson's Behavioral System Model. Tomey \& Alligood (2006) menyatakan bahwa individu dipandang sebagai suatu sistem perilaku, dimana perlindungan dan pengendalian pada sistem perilaku ini sudah selayaknya terpola, distimulasikan secara berulang dan memiliki tujuan. Sistem perilaku kadang-kadang mengalami ketidakseimbangan dan individu dituntut beradaptasi terhadap perubahan agar kembali mencapai keseimbangan. Penyesuaian dan adaptasi yang berhasil akan mengoptimalkan peran dan fungsi masing-masing subsistem. yang saling berhubungan. Setiap subsistem memiliki tujuan atau fokus masing-masing, saling berkaitan dan berhubungan satu sama lain untuk membentuk suatu perilaku. Perilaku anak usia pra sekolah dipengaruhi oleh pola asuh orangtua, lingkungan keluarga, lingkungan rumah sakit, dan lingkungan masyarakat (Rahmah, 2015).

Pada penelitian lain oleh Dianita (2016) menyimpulkan bahwa story telling (bercerita) sangat efektif diimplementasikan oleh perawat selama prosedur invasif dan masa hospitalisasi anak usia pra sekolah, karena terbukti sangat signifikan dapat menurunkan kecemasan pada anak.

\section{SIMPULAN}

Gambaran perubahan ansietas anak pra sekolah yang dihospitaslisasi di RS. Raflesia Kota Bengkulu, sebelum dan setelah dilakukan terapi story telling signifikan karena adanya penurunan nilai rata-rata kecemasa sebelum dan setelah diberikan intervensi. Gambaran perubahan ansietas anak pra sekolah yang dihospitaslisasi di RS. Raflesia Kota Bengkulu, sebelum dan setelah dilakukan terapi Menonton animasi kartun signifikan karena adanya penurunan nilai rata-rata kecemasan.

Hasil uji perbedaan sebelum dan setelah terapi story telling dan terapi menonton animasi kartun, ada perbedaan yang signifikan rata-rata pretest dan posttest ke 5 terhadap perubahan kecemasan (ansietas) anak pra sekolah kelompok story telling dan terapi Menonton animasi kartun. Hasil uji perbedaan posttest perubahan kecemasan anak pra sekolah pada kedua kelompok intervensi. Dari hasil penelitian postest ke 5 antara terapi story telling dan Menonton animasi kartun didapatkan nilai rata-rata 2,00 dan 8,00. terlihat dari selisih skor kecemasan menurun 6,00 kali lebih cepat dari pada terapi Menonton animasi kartun, artinya ada perbedaan yang signifikan. Sehingga terapi story telling enam kali lebih cepat menurunkan kecemasan (ansietas) pada anak pra sekolah dimasa hospitalisasinya dibandingkan terapi menonton animasi kartun.

\section{SARAN}

\section{Pelayanan keperawatan RS Raflesia Kota Bengkulu}

Hasil riset ini dapat digunakan bagi para perawat untuk dapat mengoptimalkan perkembangan anak terutama pada anak yang mengalami ansietas dimasa hospitalisasinya.

Riset ini sebagai pedoman antisipasi dalam pendekatan yang terbaik untuk pencegahan maupun pengendalian kecemasan anak berupa kegiatan promotif, preventif, deteksi dan intervensi dini pada anak yang mengalami ansietas dapat diselenggarakan dalam bentuk kemitraan antara perawat anak pada keluarga, dengan tenaga professional lainnya sehingga akan menurunkan ansietas anak.

Perawat anak dapat memodifikasi intervensi relaxsasi anak yang mengalami ansietas yang sedang dirawat sehingga diharapkan mampu menenangkan emosional anak, mendistraksi mengurangi rasa sakit, sehingga dapat membantu perkembangan 
perilaku dan emosional anak sakit secara optimal sebagai bentuk peningkatan mutu pelayanan keperawatan anak.

\section{Pendidikan Keperawatan}

Hasil penelitian ini dapat dimanfaatkan oleh mahasiswa keperawatan maupun mahasiswa pascasarjana spesialisasi anak untuk menambah wawasan mengenai stimulasi perkembangan audio yang bervariasi dengan menggunakan terapi story telling dengan cerita si kancil dan si siput dan story telling lainya untuk mengoptimalkan perkembangan psikologis dan emosional anak yang sedang dirawat di Rumah Sakit.

\section{Penelitian Keperawatan}

Kepada peneliti yang berminat di bidang terapi edukatif dapat ditindaklanjuti lebih dalam lagi dengan berbagai jenis modifikasi terapi story telling dan varian sampel yang lebih banyak seperti pada anak berkebutuhan khusus yang sedang dihospitalisasi

\section{Orang tua}

Bagi orangtua yang memiliki anak dengan kecemasan yang sedang dianjurkan untuk sering melakukan terapi bercerita atau story telling kepada anaknya terutama diwaktu malam menjelang tidur karena terbukti signifikan lebih efektif menurunkan ansietas anak serta dianjurkan kepada para orangtua dan keluarga untuk bersama-sama menemani anaknya selama sakit agar supaya hubungan antar keluarga semakin erat.

\section{DAFTAR PUSTAKA}

Adnanda, Y. H. (2016). Tumbuh Kembang dan Terapi Bermain pada Anak. Jakarta: Salemba Medika

Apriany, D. (2013). Hubungan antara Hospitalisasi Anak dengan Tingkat Kecemasan Orang Tua. Jurnal Keperawatan Soedirman, 8(2), 92-104

Asfandiyar, Y. A. (2007). Cara Pintar Mendongeng. Bandung: PT. Mizan Pustaka

Baljit, K. (2014). Effectiveness of Cartoon Distraction on Pain Perception and Distress in Children during Intravenous Injection. IOSR Journal of Nursing and Health Science (IOSR-JNHS)

Brannon, L., Feist, J., \& Updegraff, J. A. (2013). Health Psychology : an Introduction to Behavior and Health, Eight Edition. USA: Wadsworth

Dianita, H. (2016). Pengaruh Terapi Bercerita melalui Audiovisual terhadap Kecemasan Anak Usia Prasekolah (3-6 Tahun) akibat Hospitalisasi di Rsud Kabupaten Semarang. Jurnal Kesehatan Stikes Ngudi Waluyo

Fradianto, I. (2014). Pengaruh Terapi Bermain Lilin terhadap Penurunan Tingkat Kecemasan pada Anak Usia Prasekolah yang Mengalami Hospitalisasi di RSUD Dr. Soedarso Pontianak. Universitas Tanjung Pura Pontianak

Haryadi, H. (2015). Karakteristik Masa Anak Usia Pra Sekolah. https://ayumaghfurroh.wordpress.com

Hawari, H. (2011). Manajemen Stres Cemas dan Depresi. Jakarta: FKUI

Hidayat, A. A. (2012). Pengantar Ilmu Keperawatan Anak. Jakarta: Selemba Medika

James, J., Ghai, S., \& Sharma, N. (2012). Effectiveness of"Animated Cartoons" as a Distraction Strategy on Behavioural Response to Anxiety and Pain Perception among Children Undergoing Venipuncture. Nursing and Midwifery Research Journal, 8(3), 198-209 
Kanchan, L. A. (2014). Efektifitas Terapi Mendongeng terhadap Kecemasan Anak Usia Toddler dan Prasekolah Saat Tindakan Keperawatan

Keliat, K. (1999). Manajemen Kasus Gangguan Jiwa: CMHN (Intermediate course). Jakarta: EGC

Lee, J. (2012). Cartoon Distraction Allevietas Anxiety in Children During Induction of Anesthesia. Anesthesia \& Analgesia, 115(5)

Lumbansiantar, R. (2012). Pengaruh Story Telling terhadap Tingkat Kecemasan Akibat Hospitalisasi pada Anak Usia Prasekolah di RSUD Kota Bekasi

Maharezi, S. (2014). Pengaruh Teknik Distraksi (Boneka Tangan) terhadap Perubahan Skala Nyeri saat Imunisasi Campak pada Bayi di Wilayah Kerja Pustu Bulakan Balai Kandi, Koto Nan IV, Payakumbuh Barat. Universitas Muhammadiyah Sumatera Barat

Nursalam, N. (2013). Asuhan Keperawatan Bayi dan Anak. Jakarta: Salemba Medika

Parker, T. S., \& Wampler, K. S. (2010). Changing Emotion: The Use of Therapeutic Storytelling. Journal of Marital and Family Therapy, 32, 155-166

Pratiwi, Y. S. (2012). Penurunan Tingkat Kecemasan Anak Rawat Inap dengan Permainan Hospital Story di RSUD Kraton Pekalongan. Jurnal Ilmiah Kesehatan STIKES Muhammadiyah Pekajangan Pekalongan;(online), (http://journal.stikesmuh-pkj.ac.id) diakses 6 Oktober 2017

Pravitasari, A., \& Edi, W. B. (2014). Perbedaan Tingkat Kecemasan Pasien Anak Usia Prasekolah Sebelum dan Sesudah Program Mewarnai. Jurnal Nursing Studies; (online), http://ejournals1.undip.ac.id/index.php /jnursing. Diakses 5 Oktober 2017

Rahmah, S. (2015). Hubungan Penerapan Atraumatic Care dengan Stres Hospitalisasi pada Anak di Ruang Anak Rumah Sakit Umum Cut meutia Kabupaten Aceh Utara. Jurnal Kesehatan Almuslim, (2)

Riskesdas. (2013). Hasil Riset Kesehatan Dasar.Jakarta: Riskesdas

Santoso, T., Tatik, H., \& Nanik, P. (2009). Mendidik tanpa Menggurui melalui Dongeng Anak. Jurnal Pedalangan, 7(2), 214-227

Sarfika, R. (2015). Pengaruh Teknik Distraksi Menonton Kartun Animasi terhadap Skala Nyeri Anak Usia Prasekolah saat Pemasangan Infus di Instalasi Rawat Inap Anak RSUP dr.M. Djamil Padang. Jurnal Ners Jurnal Keperawatan, 11(1), 3240

Stuart, S., \& Sundeen, S. (2008). Buku Saku Keperawatan Jiwa. Jakarta: EGC

Subardiah, S. (2009). Pengaruh Permainan Terapeutik terhadap Kecemasan, Kehilangan Kontrol, dan Ketakutan Anak Prasekolah Selama Dirawat di RSUD Dr.H.Abdul Moeloek Propinsi Lampung. Universitas Indonesia

Sugihartiningsih, S. (2016). Menjaga Kesehatan Bayi dan Balita. Jakarta: EGC

Supartini, S. (2010). Buku Ajar Konsep Dasar Keperawatan Anak. Jakarta: EGC

Tamsuri, T. (2007). Konsep dan Penatalaksanaan Nyeri. Jakarta: EGC

Tomey, T., \& Alligood, A. (2006). Nursing Theorist and Their Work. 6th Edition, ST. Louis : Mosby Elsevier, Inc American Heart Association (AHA)

Twycross, A., Dowden, S. J., \& Bruce, E. (2009). Managing Pain in Children a Clinical Guide. USA: Blackwell

Unicef. (2013). United Nations Children's Fund.(online),(http://www.unicef.org/d prk/unicef-factsheet, diakses 7 Oktober 2017)

Utami, Y. (2014). Dampak Hospitalisasi terhadap Perkembangan Anak. Jurnal Ilmiah Widya, 2(2), 9-20 
WHO. (2015). Centers for Disease and Control Prevention. Worldwide Prevalence of Hospitalisasion. ISBN 9789241596657

Windura, W. (2008). Pengaruh Teknik Distraksi Menonton Kartun Animasi terhadap Ansietas Anak Usia Sekolah selama Hospitalisasi. Jurnal Keperawatan Unand

Wong, D. L. (2009). Buku Ajar Keperawatan Pediatrik. Jakarta: EGC 